\title{
Energy Optimisation in Office Buildings Through Daylighting Design for Climatic Conditions of Central India
}

\author{
KOMAL THAKUR ${ }^{1 *}$, K.P. REWATKAR ${ }^{2}$ \\ ${ }^{1}$ Assistant Professor, Institute of Design Education and Architectural Studies, \\ Nagpur, India \\ ${ }^{2}$ Professor, Priyadarshani Institute of Architecture \& Design, Hingna, Nagpur, India \\ *Email: komal1916@gmail.com
}

Received: September 07, 2015 | Revised: November 20, 2015 | Accepted: November 29, 2015

Published online: January 04, 2016

The Author(s) 2015. This article is published with open access at www.chitkara.edu.in/publications

\begin{abstract}
This paper is based on the premise that energy optimisation is possible in office buildings through design of daylighting. The motivation for the study was born of the fact that in India, among all building typologies, commercial buildings consume the maximum energy. This energy consumption is mainly for cooling of the building and lighting the interior spaces. Cooling and lighting up spaces generates heat in and around the building, which again increases the cooling load. Out of the total electrical energy required in the building, around $20-40 \%$ is used for lighting purposes. Despite availability of daylight during the working hours, artificial lighting is used in offices that have huge internal spaces with large spans. This paper aims at understanding the factors related to daylight penetration into office building in different situations and developing guidelines for achieving maximum daylight penetration in large spaces.
\end{abstract}

Keywords: Daylight, Office Buildings, Energy Optimisation, Daylighting Design

\section{INTRODUCTION}

Office building designs have undergone manifold changes because of various technological innovations as well as social and economic transformations. At present, intense international competition is forcing many businesses to examine and rethink their organisational structure. Modern technology is making it possible to use time and energy in offices in new creative ways. Intensive use of modern technology has created issues such as global warming, greenhouse effect and, hence, requires us to think seriously about the importance of saving energy and the necessity of designing energy efficient buildings. Lighting is the major energy consumer in commercial as well as in office buildings. 
Thakur, K Rewatkar, KP

Lighting generates heat and increases cooling load of buildings. Various tasks require different intensities and different types of lighting. Sufficient daylight is available during office hours and can be used without any load on electricity for lighting. Daylight is much more comfortable to work with as compared to artificial light. At the same time, sunlight can be very intense and, if not admitted properly in the building, can cause excessive glare, creating problem for users.

Though availability of daylight is useful for reducing energy consumption, simultaneously the designer needs to be very careful the about visual comfort of occupants. Good quality light helps to increase productivity and also saves energy. Studies show that out of the total energy consumption, 20-40\% of electricity is used for artificial lighting which can be reduced by appropriate use of daylighting [11].

\section{IMPORTANCE OF NATURAL LIGHTING FOR USER PERFORMANCE}

Literature review shows that lighting produces a few acids in the human body which then increase impulse control, motivation, calmness and, concentration. Lighting also helps to increase the general well-being of the user. Eye strain, which is considered as a large-scale problem in offices, gets reduced with proper daylighting, resulting in reduction of stress of occupants. Some surveys and studies also reveal that good daylighting induces an increase in productivity in task performance when compared to the same task performed in poorly day-lit conditions. It is also seen that large office spaces designed on the 'open office system' and good lighting conditions also increases interaction between employees.

\section{METHODS OF STUDY}

Two methods could have been adopted for this study, the first of which is an actual field survey for readings and feedback of users, while the second could be based on techniques of simulation through computer-generated models. Since the case studies are of existing buildings in active use and, correct observations and users' feedback could be obtained, the first method was adopted

\subsection{Approaches to the Study}

Day-lighting conditions change with change of season, bringing about corresponding changes in daily illumination levels. It was out of the scope of this study to take daily readings throughout the year of illumination level of 
the chosen case examples. Readings for daylight were mainly recorded for two seasons, i.e., summer and monsoon. Maximum light and glare can be expected in summer and minimum light and glare can be expected during the rainy season with overcast sky. One particular type of day of each season was then considered for the study. The day selected during summer was a clear, sunny day. The time for taking readings was 12.00 noon $-1.00 \mathrm{pm}$. This allowed the study of an average amount of diffused light (not direct sunlight) that penetrated into the building. The day selected during monsoon was an overcast day with the kind of medium illumination found on most days of the season.

The objective of the study was to address issues related to daylight penetration in office buildings and factors which affect lighting conditions of large areas such as those found in large office buildings. The paper focuses on factors affecting daylight penetration (such as orientation, open spaces around building, vegetation around building, placement of window, layout of interiors, height of partitions, material \& colour of internal partitions) and tries to explore guidelines for designing with daylight

\subsection{The Study Framework}

The Analysis Method used is the parallel or the comparative method. Five office buildings in Nagpur (a city located in the heart of Central India) were selected for the study, out of which three were government office buildings and, the other two were privately-owned Information Technology offices. The buildings were the 'Block B of the CGO Complex', the 'Water Resource Centre', the 'Water Resource Training Centre', 'Persistant I.T. Park' and, the 'Infospectrum I.T. Park'.

\section{SURVEY FINDINGS FOR DAYLIGHTING DESIGN IN OFFICE BUILDINGS}

Surveys were conducted to calculate the light intensity in the five selected office buildings in Nagpur and intensities were plotted for summer and monsoon. Details of these buildings are given below (Table 1). The Parameters of Comparative study were Orientation, Window Sizes and Placement, Window to Wall Ratio, Illumination Level on each direction and Illumination Level at different floors.

\subsection{Case Study 1 - Illumination Level Study - Block - B, CGO Complex}

The longer facades of this building face north \& south and the window to wall ratio (i.e., the ratio of vertical fenestration area to gross vertical wall [9] is 0.34 . The windows are sunken and protected from all sides (Fig. 1a \& 1b).
Energy Optimisation in Office Buildings Through Daylighting Design for climatic Conditions of Central India

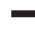

(1)


Thakur, K Rewatkar, KP
Table 1: Window to Wall Ratio, Daylight and Orientation (Source: Author)

\begin{tabular}{llll}
\hline Building & $\begin{array}{l}\text { Window to } \\
\text { wall ratio }\end{array}$ & $\begin{array}{l}\text { Max. Depth } \\
\text { of building for } \\
\text { direct light } \\
\text { penetration }\end{array}$ & Orientation \\
\hline Case Study 1: Block-B, CGO Complex & 0.34 & $20 \mathrm{~m}$ & East-West \\
Case Study 2: Persistant I.T. Park & 0.65 & $30 . \mathrm{m}$ & East-West \\
$\begin{array}{l}\text { Case Study 3: Water Resources Training } \\
\text { Centre }\end{array}$ & 0.27 & $7 \mathrm{~m}$ & North-South \\
Case Study 4: Water Resources Centre & 0.30 & $4.5 \mathrm{~m}$ & East-West \\
Case Study 5: Infospectrum I.T. Park & 0.10 & $40 \mathrm{~m}$ & East-West \\
\hline
\end{tabular}

Figure 1a (Right): Section through Window of Block-B, CGO Complex, Nagpur (Source: Author)

Figure 1b (Far Right): Façade of the Block-B, CGO Complex, Nagpur (Source: Author)

Figure 1c (Below): Chart 1 (Source: Author)

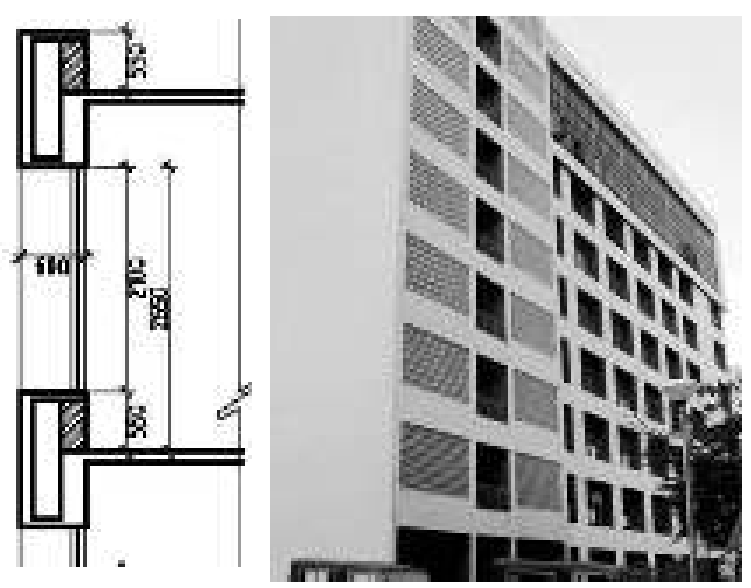

It is observed from the readings shown in Chart 1 (Fig. 1c) that the decrease in illumination level is gradual for every $1 \mathrm{~m}$ distance from the window. Maximum illumination level is seen at $1 \mathrm{~m}$ distance from the window. This, however, is as high as 800 lux which creates conditions of glare at the table top. An illumination level of 200 lux - appropriate for table top working - was found at distances of $2.0-2.5 \mathrm{~m}$ from windows. 


\subsection{Case Study 2 - Illumination Level Study - Persistant I. T. Park}

The type of window used in this building is also sunken. (Fig. 2a \& 2b). The window to wall ratio is 0.65 and the longer facades of the building face North \& South. It is observed from the readings given in Chart 2 (Fig. 2c) that decrease in illumination level is gradual for every $1 \mathrm{~m}$ distance from window. The maximum illumination level at $1 \mathrm{~m}$ distance from the window is 600 lux, which creates glare on table top. Up to a distance of $2 \mathrm{~m}$ from window, the illumination level is 200 lux, which is ideal for table top working. Because of the use of tinted glass on windows, the maximum level of illumination -- as compared to the first case study -- is less even if the window size is bigger.

Figure 2a(Right): Section through Window of Persistant I.T. Park, Nagpur (Source: Author)

Figure 2b (Far Right): Façade of the Persistant I.T. Park, Nagpur (Source: Author)

Figure 2c (Below): Chart 2 (Source: Author)
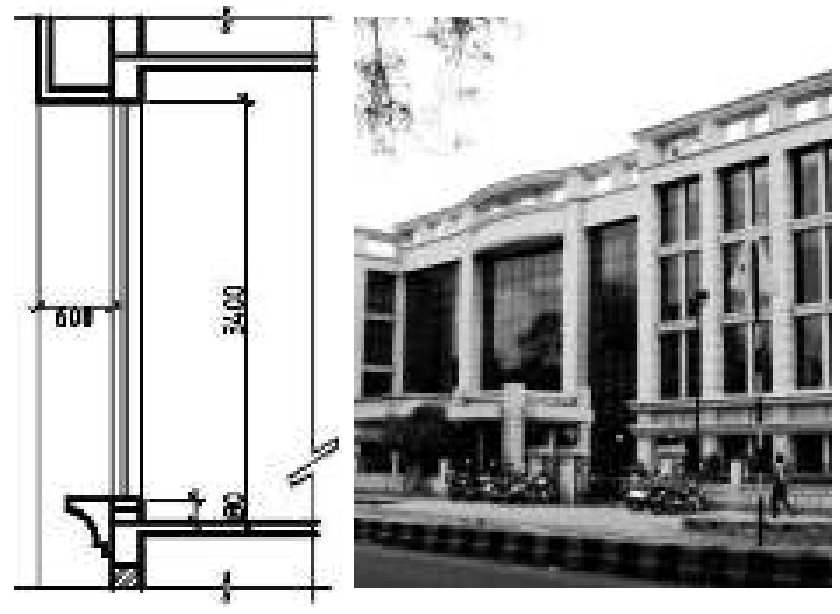

Energy Optimisation in Office Buildings Through Daylighting Design for climatic Conditions of Central India

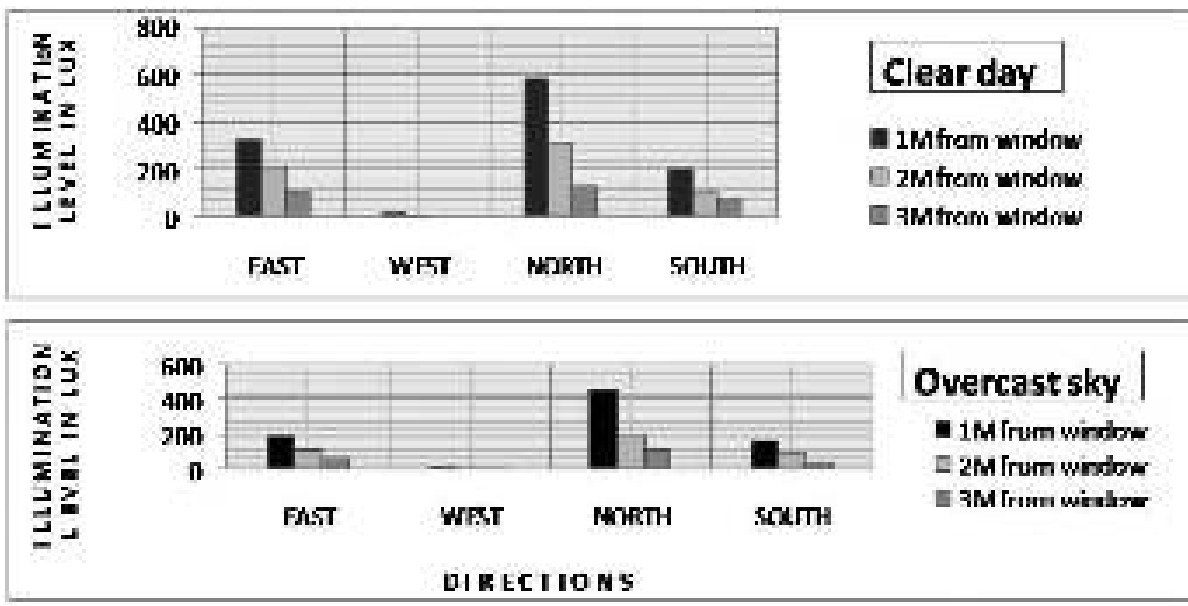


Thakur, K Rewatkar, KP

\subsection{Case Study 3 - Illumination Level Study - Water Resource Training Centre}

The type of window used her is plain with a cantilevered chajja above it (Fig. 3a and 3b). The window to wall ratio is 0.27 and the longer facades face East \& West. There are no openings on the North \& South facades. It is observed from the readings given in Chart 3 (Fig. 3c) that the maximum level of illumination at $1 \mathrm{~m}$ distance from the window is 1000 lux. It suddenly decreases to 400 lux at $2 \mathrm{~m}$ and the light penetration is gradual. Though the window to wall ratio is less, the building is well lit and gets sufficient natural light on table tops. As the depth of the building is less that is $7 \mathrm{~m}$. high illumination causes problem on table tops located near the windows.

Figure 3a: Section through Window of Water Resource Training Centre, Nagpur (Source: Author)

Figure 3b: Façade of the Water Resource Training Centre, Nagpur (Source: Author)

Figure 3c: Chart 3 (Source: Author)

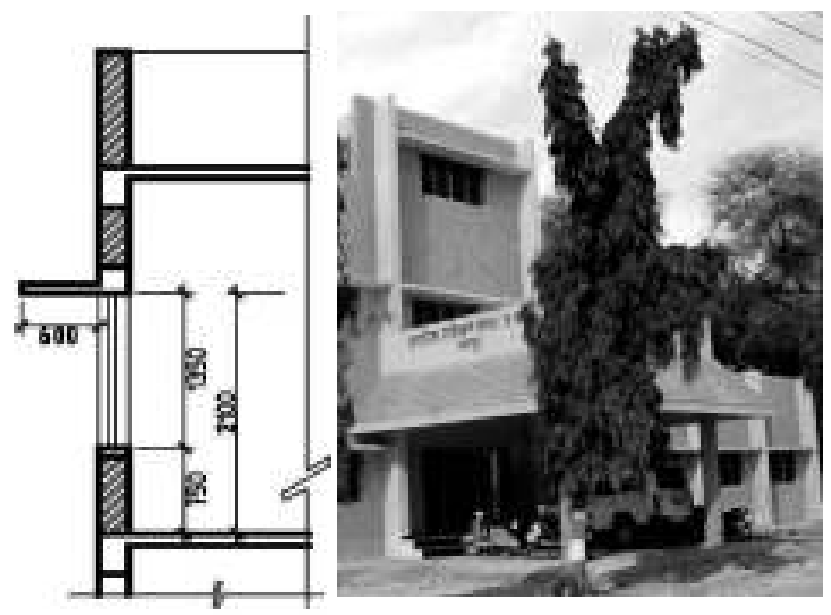

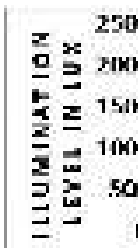
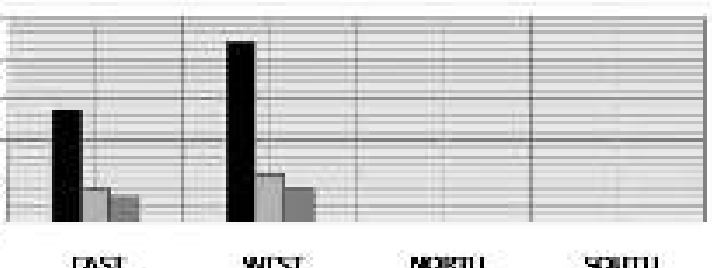

Clear day

- 1 Maficen windras

C YaAficm voncton

E 3Mfrom window

Inst

WIST

Rakn।

Gxit1

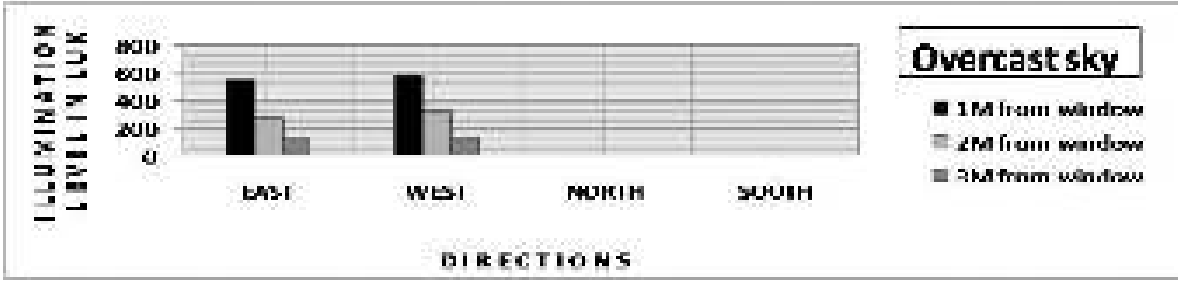




\subsection{Case Study 4 - Illumination Level Study - Water Resource Centre}

The type of window used here is sunken (Fig $4 \mathrm{a} \& 4 \mathrm{~b}$ ), with a window to wall ratio of 0.30. There are no openings on North \& South facades. It is observed from readings shown in Chart 4 (Fig. 4c)that decrease in illumination level is gradual for every $1 \mathrm{~m}$ distance from window. Sufficient amount of illumination is received up to $2.5 \mathrm{~m}$. In this building interior spaces are partitioned by walls and distance from window to wall is up to 4.0 to $4.5 \mathrm{~m}$. This creates dark patches near partition walls. Maximum illumination level at $1 \mathrm{~m}$ distance from window is 800 lux which creates glare on table top. Up to $2-2.5 \mathrm{~m}$ from window, the illumination level is 200 lux, which is as required on table tops for working.

Figure 4a (Right): Section through Window of the Water Resource Centre, Nagpur (Source: Author)

Figure 4b (Far Right): Façade of the Water Resource Centre, Nagpur (Source: Author)

Figure 4c (Below): Chart 4 (Source: Author)

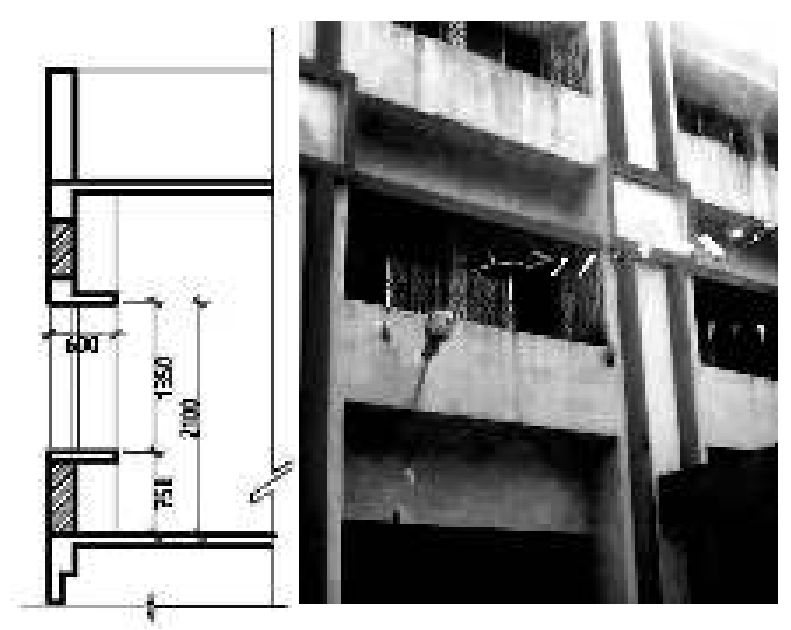

Energy Optimisation in Office Buildings Through Daylighting Design for climatic Conditions of Central India

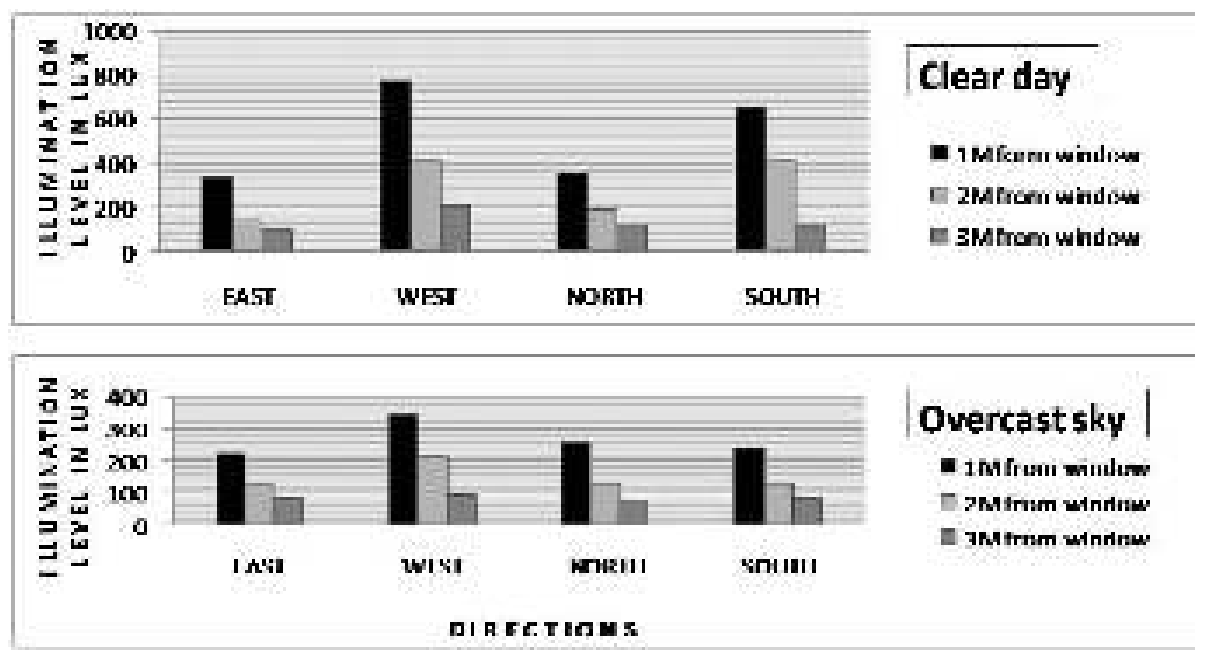


Thakur, K Rewatkar, KP

\subsection{Case Study 2 - Illumination Level Study - Infospectrum I. T. Park}

The type of window used in this building is plain (Fig 5a \& 5b) and the window to wall ratio is 0.10 . There are very few windows to this building. It is observed from the readings in Chart 5 (Fig. 5c) that decrease in illumination level is gradual for every $1 \mathrm{~m}$ distance from window. Maximum amount of illumination at $1 \mathrm{~m}$ distance is $150 \mathrm{lux}$, which is less than what is required for comfortable regular work. Span of this building is $40 \mathrm{~m}$ which leaves several areas completely in dark.

Figure 5a (Right):

Section through Window of the Infospectrum I. T. Park, Nagpur (Source: Author)

Figure 5b (Far Right): Façade of the Infospectrum I. T. Park, Nagpur (Source: Author)

Figure 5c (Below): Chart 5 (Source: Author)
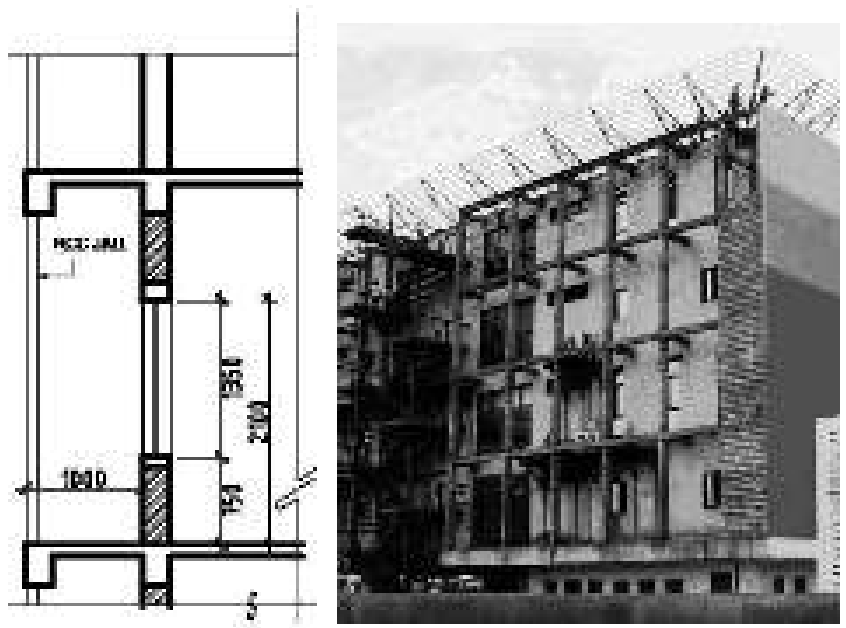


\subsection{Summary of Findings and Observations.}

- The ideal window to wall ratio on East and West facades is 0.3-0.4 [7]. If the ratio goes above this range, the windows should be designed carefully as the low sun angles for these orientations makes the design of their shading extremely difficult.

- The ideal light intensity at table top is 200 lux. The light intensity in all types of windows studied (Fig. 6) is more than 300 lux up to a distance of $2.00 \mathrm{~m}$ from windows. This is more than the ideal light intensity of 200 lux and causes disturbing glare on table tops. Light intensity should be controlled to reduce glare in these areas without interrupting daylight penetration beyond $2.0 \mathrm{~m}$.

- After the distance of $2 \mathrm{~m}$ from windows, light intensity suddenly starts decreasing by about $50 \%$ for every $1 \mathrm{~m}$. This reduction can be worked on to increase the daylight penetration

- In the case of small windows with lesser height (i.e., $1.35 \mathrm{~m}$ ), light (with required intensity of 200 lux) reaches up to a maximum distance of $3.00 \mathrm{~m}$ and, in case of full height windows light reaches up to a maximum distance of $3.50 \mathrm{~m}$

- Windows having protection on top admit more light upto the first one meter as compared to sunken or projected type windows.
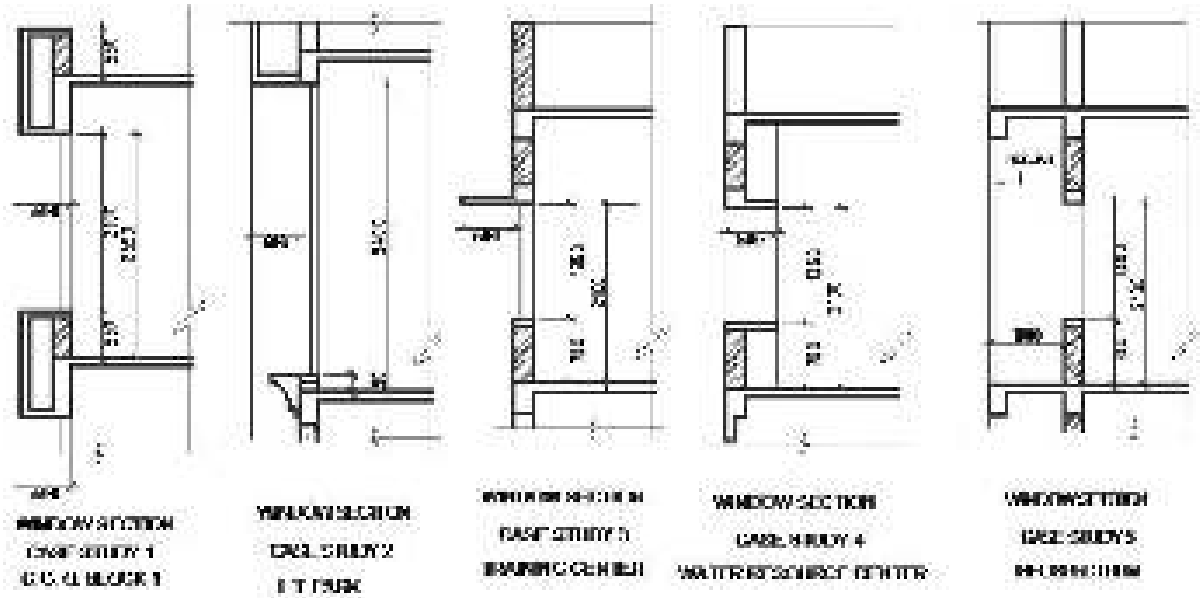

Figure 6: A comparison of window sections of all case studies, showing sill, lintel and window projection / protection (Source: Author)
Energy Optimisation in Office Buildings Through Daylighting Design for climatic Conditions of Central India 
Thakur, K Rewatkar, KP

\section{GUIDELINES FOR DAYLIGHTING DESIGN IN OFFICE BUILDINGS}

\subsection{Consideration for Designing the Guidelines}

Office timing considered: 9.00 am to $6.00 \mathrm{pm}$

\subsection{Orientation:}

The study shows that the maximum illumination during the summer and monsoon months is on the West and the North sides, whereas in winter, it is on the South and West sides. The preferred shape of the building should be rectangular with the axis making an angle of $0-30$ degrees with the E-W direction. With this orientation, the maximum level of daylight and thermal comfort will be achieved. In the Central Region of India, the normal office timings are $9.00 \mathrm{am}$ to $6.00 \mathrm{pm}$. Out of these 9 hours, the sun is on the west side for 6 hours. Planning should be done with this fact and the thermal comfort in mind. Probable locations of service cores are shown in the images, so that the maximum amount of light can be admitted inside the working areas. These conditions are true for a building width up to $8 \mathrm{~m}$, with windows on both the longer sides (Fig.7). Wherever the ideal orientation is not feasible, the building may be reoriented according to the site conditions.

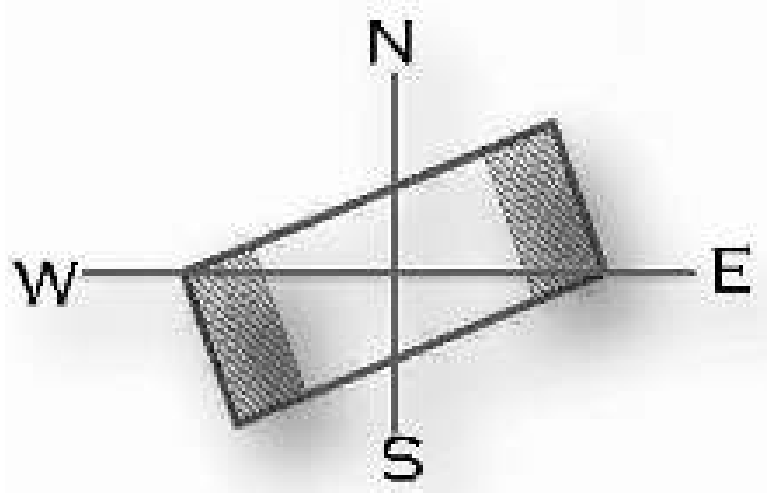

Figure 7 (Left): Preferred shape and orientation of Office Buildings located in Central India (Source: Author)

\subsection{Depth of Building for Regular Windows}

If working with windows of width $2.0 \mathrm{~m}$, height $1.5 \mathrm{~m}$ and, sill height of $0.6 \mathrm{~m}$, and windows located on both sides of the building opposite to each other, and a window to wall ratio between $0.3-0.4$, the depth of the building 
block should not be more than $7.0 \mathrm{~m}$. However, in all cases sufficient care should be taken to reduce glare near windows and provision should be made so that glare and heat gain will be minimised without reducing the intensity of light.

Figure 8 (Centre): The Courtyard Advantage (Source: Author)

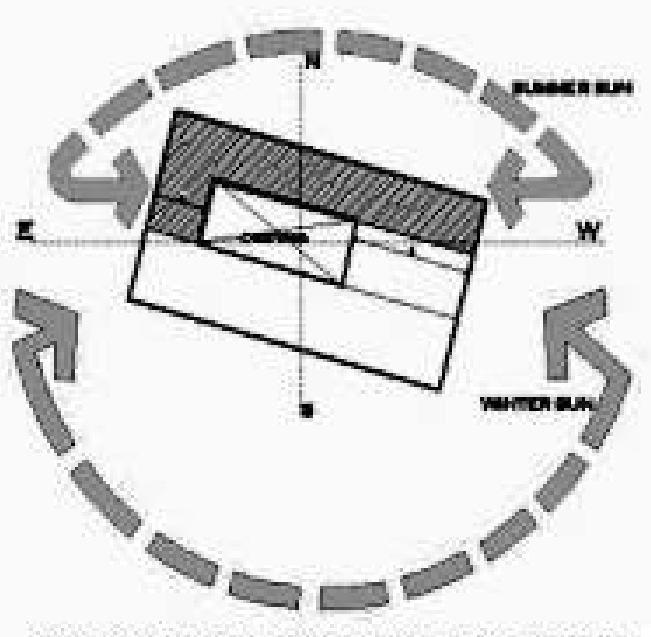

ENPCETONDUFINGEMARTAN WNTER

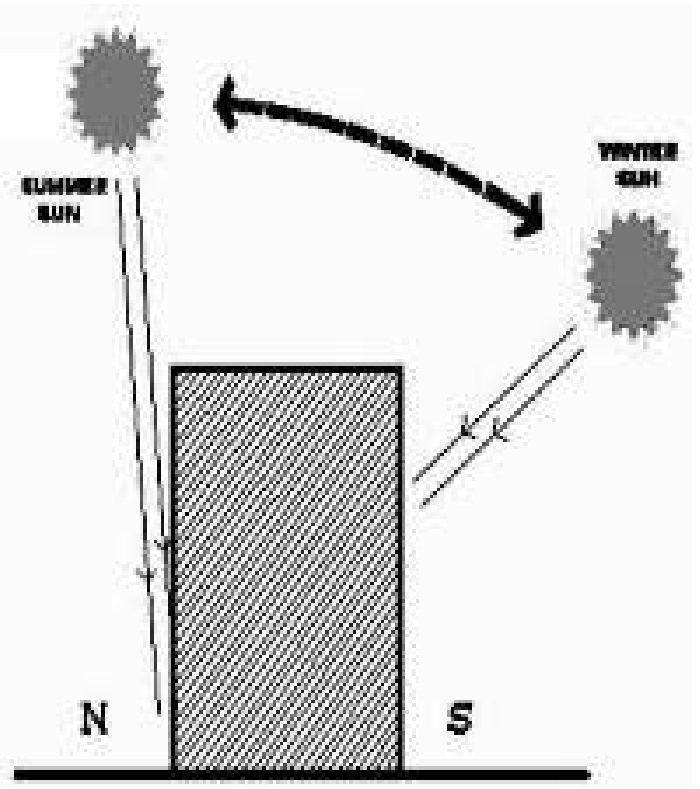

Energy Optimisation in Office Buildings Through Daylighting Design for climatic Conditions of Central India
Figure 9 (Right): Summer and Winter Sun Angles (Source: Author) 
Thakur, K

Rewatkar, KP

\subsection{Courtyards}

Courtyards that help to provide good light and ventilation to a building from two sides, can play a major role in daylighting design. Since the office space is used between $9.00 \mathrm{am}$ to $6.00 \mathrm{pm}$, the time period before noon (when sun angles are low) is less and that in the afternoon (with higher sun angles) is more. The advantage of courtyard layout is that reflected diffused light will enhance illumination level through windows on opposite sides of the interior spaces.(Fig. 8 \& 9). Also, considering the sun angles and positions, maximum sun light will be achieved during winter and its penetration avoided during summer. Courtyards can also be used for plantation and water bodies, thereby increasing the cooling of interiors. All facades should be designed with light shelves to get maximum of daylight (Fig. 10 \& 11).

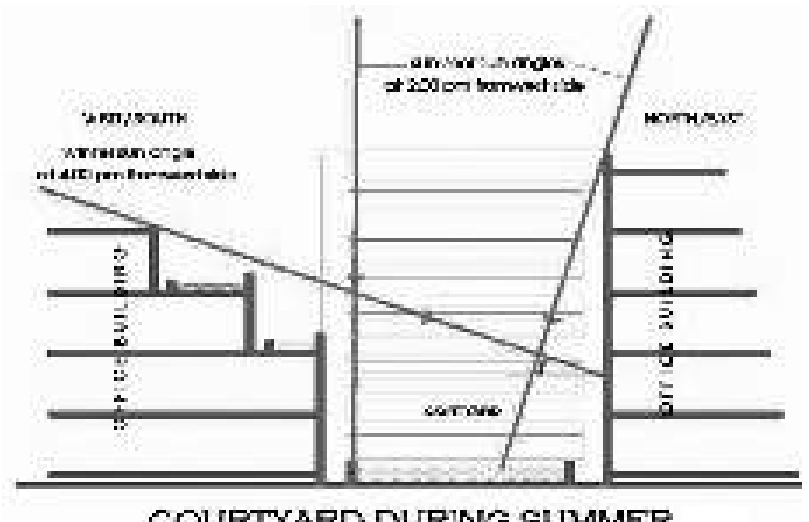

COURTYARD DURING GUMMER

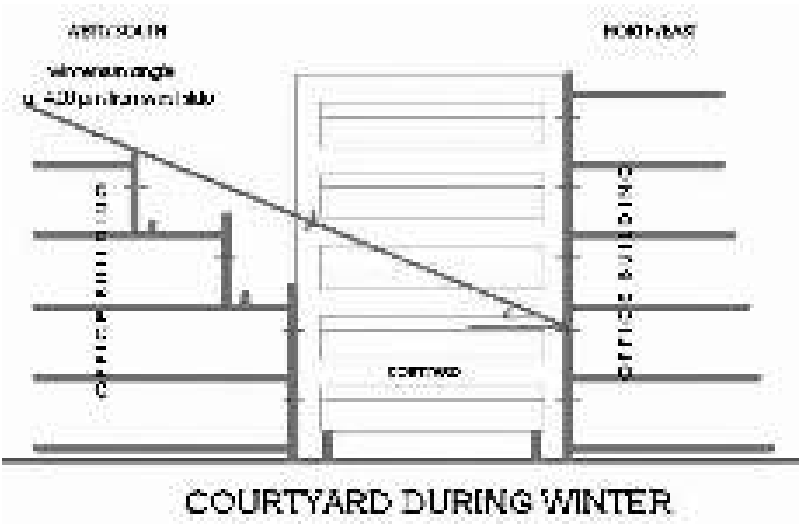

Figure 11: Winter sun penetration in buildings around courtyards (Source: Author)

Figure 10: Summer sun penetration in buildings around courtyards (Source: Author) 


\subsection{Design of Facades and Fenestrations}

The Lawrence Berkley National Laboratory has developed window shelves and light pipes for efficient penetration of daylight inside building. According to the published data by this laboratory windows designed above $2.10 \mathrm{~m}$, i.e., above lintel level, provide diffused natural daylight and prevent glare. Consideration of facade direction and sun angle increases efficiency. Horizontal shelf with louvers above and coating of reflective surfaces allow for reflection and deep penetration of sunlight. Adjustable louvers ensure maximum penetration of light. Maximum distance that can be traveled by light with this arrangement during summer is $6.5 \mathrm{~m}$ and during winter is $10.0 \mathrm{~m}$. The regular window arrangement can be provided at normal height up to $2.1 \mathrm{~m}$. This window is horizontally pivoted so it can be used to monitor winter sun penetration. If the window glass is coated with dielectric layer it will reflect maximum light during summer and will not cause glare problem and help to control heat gain.

To reflect more sun light during winter it is also possible provide the shelf without louvers. In that case the shelf itself will be adjustable for various angles of sun during different seasons. If the glass panel is open, louvers will act as ventilators during summer to expel the hot air from office spaces (Fig. $12 \& 13$ ).

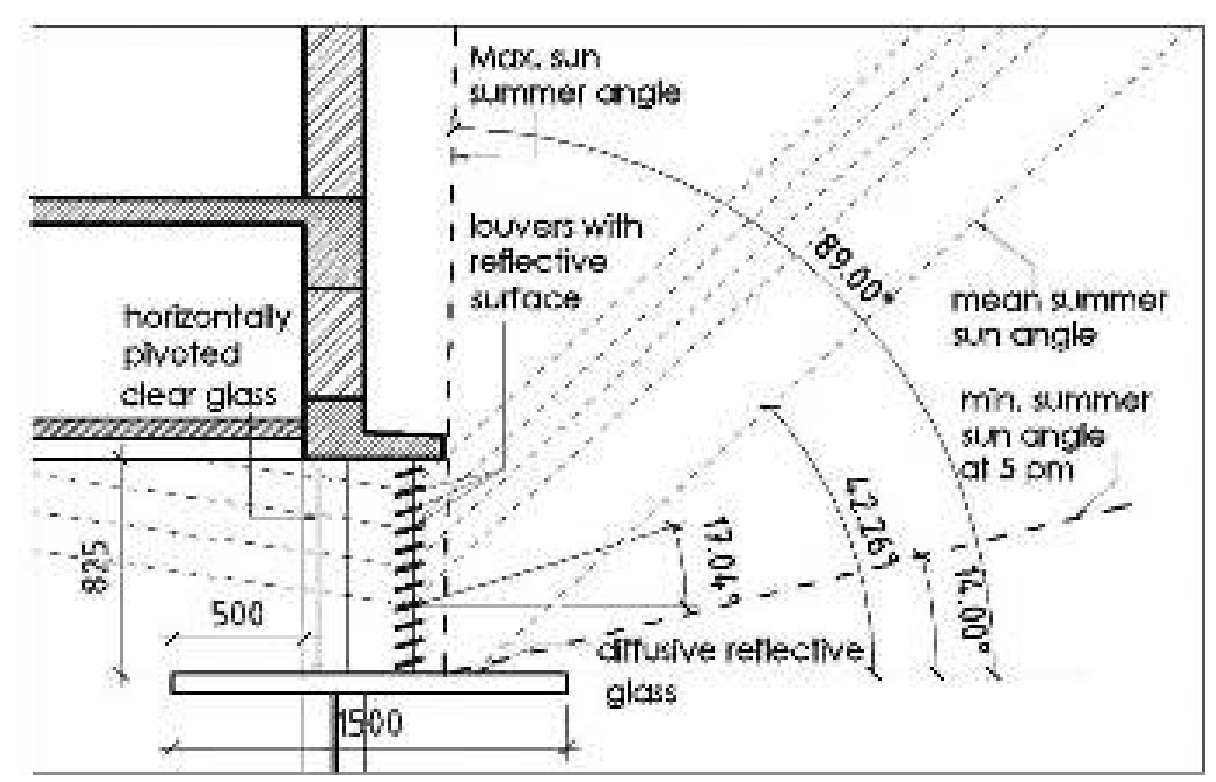

Figure 12: Window Detail showing Light Penetration (Source: Schematic sections developed by author with reference of Lawrence Berkeley Research Laboratory's published data)
Energy Optimisation in Office Buildings Through Daylighting Design for climatic Conditions of Central India

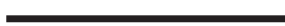


Thakur, K Rewatkar, KP

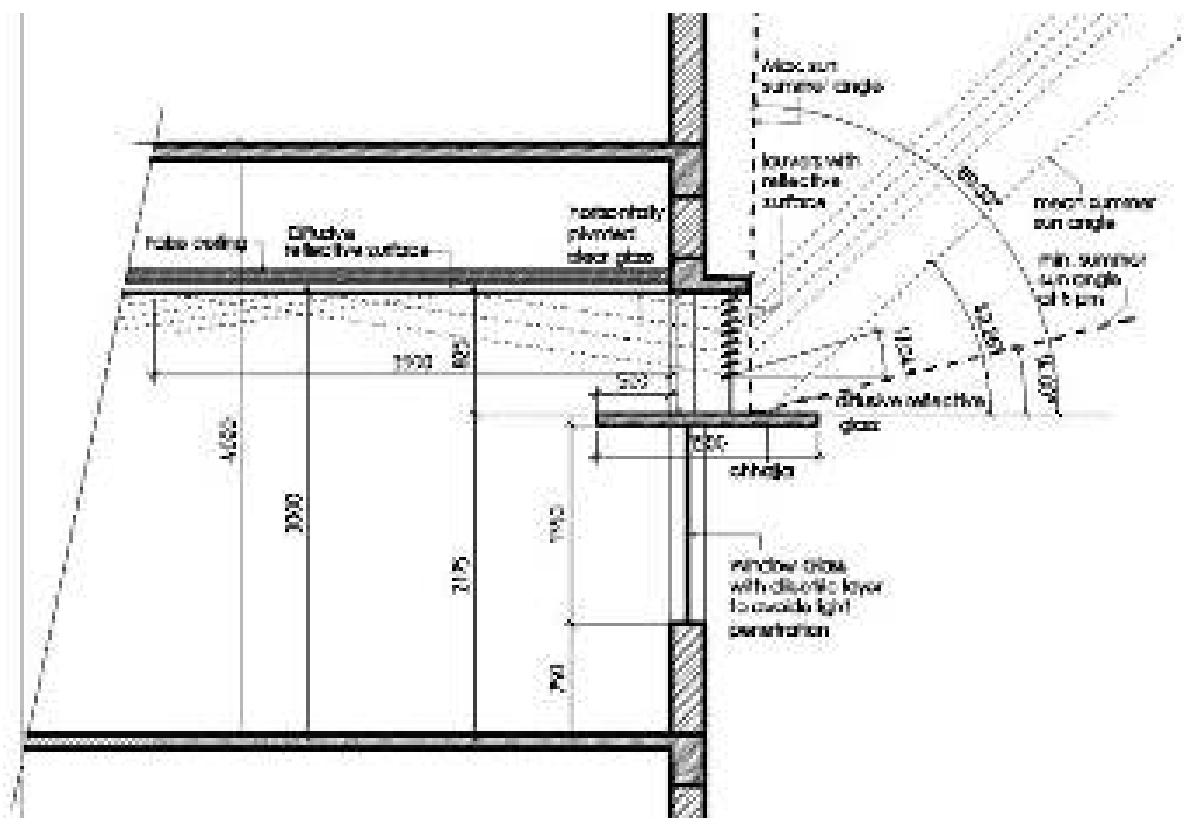

Figure 13: Light Shelf Detail showing Light Penetration (Source: Schematic sections developed by author with reference of Lawrence Berkeley Research Laboratory's published data)

The Solar pipe system consists of a pipe that transmits ambient sunlight to desired location in the building interiors. The heart of the sun pipe system consists of a mirror-finished, highly reflective aluminumtube which is electrolytically enhanced anodized aluminum. A clear polycarbonate top dome seals the light pipe and a prismatic polycarbonate ceiling fitting evenly diffuses light into the room or space below. The sun pipe system is highly effective in both sunny and overcast conditions and even when it is raining [3].

\section{CONCLUSIONS \& LIMITATIONS}

In this study, daylight penetration in office buildings for various types of windows was studied. The impact of factors such as window size, its placement, window to wall ratio, height of floor, type of window protection on daylight penetration was calculated. Increase in window to wall ratio increases daylight penetration but also tends to increase heat gain inside the office building. Office buildings can benefit from ample amount of daylight due to duration of working hours in daylight. Thus, penetration of light is possible by appropriate design solutions 
and using light shelves with louvers during summer and winter and can help in energy optimisation in artificial lighting. The initial cost and installation cost of light shelves is $60 \%-75 \%$ more than traditional window cost. But this cost can be compensated within 5 - 6 years from installation.

\section{REFERENCES}

[1] BROWNING, W.(1992) NMB Bank Headquarters: putting environmental concerns first can result in big payoffs, as this Amsterdam office building proves. Urban Land. 51(6). p. 23-25.

[2] CBRI (1968) Solar Data Book, Roorkee: Central Building Research Institute

[3] DELTA PYRAMAX ENGINEERING LTD. (n.d.) Suncatcher. Available from: http://www. sunpipe.com.hk/Sunpipe.files/SunCatcher.htm. [Accessed: 19 March 2016]

[4] ECO3. (2011) Energy Conservation Building Code Tip Sheet: Building Envelope, Version 3.0. Available from: http://eco3.org/wp-content/plugins/downloads-manager/upload/Envelope $\% 20$ Tip\%20Sheet\%20(V-3.0\%20March\%20. [Accessed: 10 December 2015]

[5] EDWARDS, L. and TORCELLINI, P. (2002) A Literature Review of the Effects of Natural Light on Building Occupants. Colorado: National Renewable Energy Laboratory (NREL). Available from: www.nrel.gov. [Accessed: 21 February 2016]

[6] FRANTA, G., ANSTEAD, K. (1994) Daylighting Offers Great Opportunities. Window \& Door Specifier-Design Lab. Spring. p. 40-43.

[7] HEERWAGEN, J.H. (2000) Green Buildings, Organizational Success, and Occupant Productivity. Building Research and Information. 28(5). p. 353-367.

[8] HESCHONG, L.(2007) Lecture on daylight at the second VELUX Daylight Symposium in Bilbao. Available from:www.da.velux.com. [Accessed: 25 March 2016]

[9] INDIAN BUILDING ENERGY CODE COMMUNITY. Available from: https://ibecc.in. [Accessed: 23 March 2016]

[10] KRISHAN, A. (2001) Climate Responsive Architecture: A design Handbook for Energyefficient Buildings. New Delhi: Tata McGraw Hill.

[11] MADHYA PRADESH PASCHIM KSHETRA VIDYUT VITARAN COMPANY LTD. Available from: www.mpwz.co.in. [Accessed: 23 March 2016]

[12] MCNEIL, A. and LEE E.S. (2013) Annual daylighting performance of a passive optical light shelf in sidelit perimeter zones of commercial buildings., 2013.Lawrence Berkeley Research National Laboratory. Available from: http://eetd.lbl.gov/sites/all/files/passive_optical_light_ shelf.pdf. [Accessed: 04 January 2016]

[13] SUN, L. et al (2015) Dynamic Performance of the Shading-type Building-Integrated Photovoltaic Claddings. Procedia Engineering. 121. p. 930-937. Available from: https://www. researchgate.net/publication/283944290_Dynamic... [Accessed: 22 January 2016]

[14] VELUX EDITORIAL.(2007) Framing Daylight. Daylight \& Architecture. Autumn (6). p. 3 ... Available from: http://da.velux.com/ar-LB/Documents/PDFs/DA07_Complete.pdf. [Accessed: 29 April 2016]

[15] VELUX MEDIA CENTRE. (2007) press.velux.com, Press Release: Daylight must be givenhigher priority. Available from: press.velux.com/daylight-must-be-given-higher-priority. [Accessed on: 22 January 2016]
Energy Optimisation in Office Buildings Through Daylighting Design for climatic Conditions of Central India

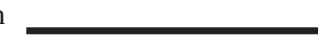

